\title{
The Factors Affecting the Intercultural Sensitivity Perception Level of Psychological Counseling and Guidance Students
}

\author{
İbrahim Tuncel ${ }^{1} \&$ Ahu Arıcıoğlu ${ }^{2}$ \\ ${ }^{1}$ Curriculum and Instruction Department, Education Science Department, Faculty of Education, Pamukkale \\ University, Denizli, Turkey \\ ${ }^{2}$ Psychological Counseling and Guidance Department, Education Science Department, Faculty of Education, \\ Pamukkale University, Denizli, Turkey \\ Correspondence: İbrahim Tuncel, Curriculum and Instruction Department, Education Science Department, \\ Faculty of Education, Pamukkale University, Denizli, Turkey. Tel: 90-0-258-296-1066. E-mail: \\ ituncel20@gmail.com
}

Received: October 20, 2017

Accepted: December 6, 2017 Online Published: February 25, 2018

doi:10.5539/ies.v11n3p61

URL: https://doi.org/10.5539/ies.v11n3p61

\begin{abstract}
The purpose of this study is to determine the factors affecting the intercultural sensitivity perception levels of Psychological Counseling and Guidance students. This study was conducted in Pamukkale University which is located in the western part of Turkey. Data were gathered from 524 freshmen, sophomore, junior and senior students who are studying in the Psychological Counseling and Guidance department. The study was designed as a survey research. As a data collection tool, "Intercultural Sensitivity Scale" which was developed by Chen and Strasto (2000) and adapted to Turkish language by Bulduk, Tosun, and Ardıç (2011) was employed. In the analysis of the data, the t-test and the one-way analysis of variance (ANOVA) were used. According to the findings of the study, it was determined that the more grade level rises, the more students' intercultural sensitivity perception level increases. It was found that the intercultural sensitivity perception levels were higher for students who stated that their experiences during undergraduate studies affected their views on cultural differences positively and for those having lived with various cultures than other participants. It was also found that the factors affecting the intercultural sensitivity perception level of students who are studying in Psychological Counseling and Guidance department are such; grade level, experience in undergraduate level, the longest place of settlement, a situation of being with different cultures. When the situation of being with different cultures increases intercultural sensitivity is considered, making widespread of international and national student exchange programs such as ERASMUS and FARABI and arranging educational settings by giving place for interaction with various cultures might be suggested.
\end{abstract}

Keywords: intercultural, intercultural sensitivity, psychological counseling candidate

\section{Introduction}

How the educational institutions and workers in such institutions evaluate and interpret personal and cultural differences is an important indicator for a democratic society. It might be said that it would be more appropriate to explain personal differences with the nature and life of a person, and trying to explain cultural differences with social, political, economic and technological developments. It is seen unavoidable that personal and cultural differences affect communication and interaction among people, institutions, and societies at the same time in terms of the communication process. Being sensitive to differences is also beneficial for both effective and suitable communication and democratic development of a society.

Firstly, making operational definitions of "culture", "cultural difference", "interculturalism", "intercultural competence", and "intercultural sensitivity" used in this research study and explaining the relations among these concepts are thought to be useful in terms of the clarity of this study. When the literature is examined, there are many and various definitions of culture. However, in this study, the definition of culture which was based given by Güvenç (1997) as "a complex whole which is consisted of all moral and material things that a human being as a member of society learns, and teaches by experiencing and doing it" (p. 15).

It is possible to reveal what a cultural difference means by closely examining the definition of culture. In this 
context, "cultural differences" might be named as the differences in belief, knowledge, art, traditions, habits and skills as being a member of a society; differences in main material and spiritual characteristics that define the society that one is belonged to; differences in lifestyles, differences in basic human rights and value judgments of a person.

Another term that needs to be explained is "interculturalism" which emerges when different cultures encounter and interact with each other. What is meant by interculturalism is not a social structure as in multiculturalism because interculturalism is a process of interaction. Designing the interaction process among people from various cultures on the basis of equality and mutual respect is called interculturalism. Interculturalism might not be assured without communication. Communication is a prerequisite condition for the formation of cultures and naturally for interculturalism (Bolten, 2007, pp. 22-24; Leclerqc, 2003, p. 9).

All competencies that individuals should have in order to create an effective and suitable intercultural communication and interaction process are defined as "intercultural communication competence". When literature is examined, it is seen that there are various models that aim to explain intercultural communication competence (Bennett, 1993; Byram, 1997; Deardorf, 2006; Howard-Hamilton, Richardson \& Shuford 1998; Imahori \& Lanigan, 1989). Chen and Starosta (1996) named affective process related with acquiring intercultural communication competence as intercultural sensitivity; cognitive process as intercultural awareness; and behavioral process as intercultural adroitness. Cognitive dimension of intercultural competence includes competencies such as recognizing own and other cultures and identifying similar and different aspects of cultures. Behavioral dimension involves competencies such as observing interaction, analyzing, evaluating, being flexible, using a language effectively and appropriately in a culture different from own culture. Affective dimension comprises characteristics such as accepting differences, respect for different cultures, tolerance, being open-minded, and having interest in different cultures (Auernheimer, 2010; Byram, Gribkova, \& Starkey, 2002; Chen \& Starosta, 1996; Hesse \& Göbel, 2007; Spitzberg \& Changnon, 2009). This study is limited to "intercultural sensitivity" which is the affective dimension of intercultural competence.

Intercultural sensitivity is a desire and tendency that motivate to behave effectively and appropriately in intercultural interaction process (Chen, 1997). According to "The Developmental Model of Intercultural Sensitivity (DMIS)" developed by Benett (1993), development of intercultural sensitivity appears in two stages. The first stage is Ethnocentric Stages which starts with denial of cultural differences (Denial), then defending own culture (Defense), and ending with disdaining other cultures (Minimization). The second stage is Ethnorelative Stages which starts with accepting cultural differences (Acceptance) and ending with an adaptation to cultural differences (Adaptation) and Integration. Intercultural sensitivity can be seen as a tendency to evaluate cultural differences while both being far from ethnocentrism and without using stereotypes and having no prejudices.

There are studies conducted with university students from various disciplines regarding intercultural sensitivity in Turkey (Baykara, 2010; Bekiroğlu \& Balc1, 2014; Bulduk, Tosun, \& Ardıç, 2011; Harmandaoğlu, 2013; Rengi \& Polat, 2014; Tertemiz \& Aslantaş, 2016; Üstün, 2011; Yılmaz \& Göçen, 2013). However, when the studies conducted in Psychological Counseling and Guidance field in Turkey (Aydın, 2014; Bektaş, 2006; Erdur-Baker, 2007; Kağnıc1, 2014; Karaırmak, 2008) are examined; any study investigating and describing perception levels of Psychological Counseling and Guidance students on intercultural sensitivity with a quantitative method couldn't be reached.

Examining the perceptions of and sensitivity to cultural differences of the practitioners in all education levels might bring enormous contributions in organizing teaching-learning process (Rengi \& Polat, 2014, p. 137-138). Sensitivity to differences is seen as one of the basic competencies of psychological counselors. In constructivist approach, it is stressed that culture has a great place in personal realities. For that sense, it might be concluded that choosing appropriate methods accordingly to counselees' culture in psychological counseling process is a must. Because of fostering intercultural sensitivity leads to an increased empathic approach to higher levels, it might also ensure the effective use of psychological counseling competencies (Kararrmak, 2008). Regulations that might develop Psychological Counseling and Guidance students' intercultural sensitivity should be realized in undergraduate programs (Erdur- Baker, 2007).

When literature is examined, intercultural sensitivity is considered in terms of such variables as; the longest place of settlement (Üstün, 2011) and a situation of being with different cultures (A. Demir \& S. Demir, 2009; Üstün, 2011). In this study, in addition to these variables, gender, experience in undergraduate studies and grade levels were also examined.

It might be thought that determining the factors affecting the intercultural sensitivity perceptions of psychological counselor candidates might contribute to curriculum development in intercultural sensitivity and the results of this 
study might also provide a base in need analysis phase. Furthermore, determining the variables which positively affect PGC students' level of intercultural sensitivity might play a role in considering these variables in PGC undergraduate programs. Therefore, with these reasons, the purpose of this study is to determine the factors affecting the intercultural sensitivity perception level of psychological counseling and guidance students. In this line, this study sought to answer following questions:

1) What are the intercultural sensitivity perception levels of students who are studying in Psychological Counseling and Guidance department?

2) Is there a significant difference between the intercultural sensitivity perception level of students who are studying in Psychological Counseling and Guidance department in terms of gender?

3) Is there a significant difference in terms of grade levels?

4) Is there a significant difference in terms of the change of view on cultural differences arising from their experiences during undergraduate studies?

5) Is there a significant difference in terms of the longest place of settlement?

6) Is there a significant difference in terms of the variable of being together with people from other cultures?

\section{Method}

\subsection{Research Model}

This study is designed as a survey research because of aiming to investigate the intercultural sensitivity perception level of psychological counseling and guidance students in terms of various variables.

\subsection{Study Group}

The study was conducted in Pamukkale University which is a state university and located in the western part of Turkey. There are 526 females and 278 males in total 804 students who are studying in Psychological Counseling and Guidance department during the 2015-2016 academic year in 1st, 2nd, 3rd, and 4th grades. Instead of using a sample, it is pursued to reach to the whole population; however, data were gathered from 524 volunteered students.

Table 1. The distribution of students' longest place of settlement in terms of regions

\begin{tabular}{lcc}
\hline Region & $f$ & $\%$ \\
\hline Central Anatolian & 32 & 6.1 \\
Black Sea & 10 & 1.9 \\
Eastern Anatolian & 17 & 3.2 \\
Southeastern Anatolian & 14 & 2.7 \\
Marmara & 38 & 7.3 \\
Aegean & 313 & 59.7 \\
Mediterranean & 100 & 19.1 \\
\hline Total & 524 & 100.0 \\
\hline
\end{tabular}

As it is seen in Table 1, when the distribution of regions of which students who participated to the study examined; Aegean region (59.7\%), and Mediterranean region (19.1\%) that students lived were seen as having the largest proportions. In other words, it might be stated that $78.8 \%$ of students come from the western part of Turkey.

Table 2. The distribution of socio-demographic characteristics of students participated to the study

\begin{tabular}{lccc}
\hline Category & & $f$ & $\%$ \\
\hline \multirow{2}{*}{ Gender } & Female & 373 & 71.2 \\
& Male & 151 & 28.8 \\
& Freshman & 117 & 22.3 \\
Grade & Sophomore & 143 & 27.3 \\
& Junior & 159 & 30.3 \\
& Senior & 105 & 20.0 \\
Socio-economic perception status & Low & 38 & 7.3 \\
& Medium & 455 & 86.8 \\
& High & 31 & 5.9 \\
\hline
\end{tabular}




\begin{tabular}{lccc}
\hline \multirow{2}{*}{ Living in a multicultural place } & Yes & 201 & 38 \\
& No & 323 & 61.6 \\
Being together with people from other cultures & Yes & 428 & 81.7 \\
& No & 96 & 18.3 \\
& Illiterate & 24 & 4.6 \\
Mothers' educational level & Primary School & 256 & 48.9 \\
& Secondary school & 71 & 13.5 \\
& High School & 124 & 23.7 \\
& University & 49 & 9.4 \\
Fathers' education level & Illiterate & 5 & 1.0 \\
& Primary School & 155 & 29.6 \\
& Secondary school & 77 & 14.7 \\
& High School & 140 & 26.7 \\
Settlement & University & 147 & 28.1 \\
& Metropolitan & 181 & 34.5 \\
Total & Small city & 105 & 20.0 \\
& Country & 161 & 30.7 \\
& Town & 30 & 5.7 \\
& Village & 47 & 9.0 \\
& & 524 & 100.0 \\
\hline
\end{tabular}

When Table 2 examined, $71.2 \%$ of the students who participated to the study were female, $86.6 \%$ of them perceive themselves as having medium socio-economic status, and $61.6 \%$ of them think that the place they live is not multicultural. The percentage of who is being together with people from other cultures (education, tourism, travel, living there, etc.) is 81.7 . It is seen that in terms of fathers' education level, $29.6 \%$ of them has a primary level, and $28.1 \%$ of them has a university level education while in terms of mothers' education level, $48.9 \%$ of them has a primary level and $9.4 \%$ of them has a university level education. In other words, it might be interpreted as the education level of fathers is higher than the education level of mothers of students who participated in the study.

\subsection{Data Collection Tool}

In this study, in order to measure the level of intercultural sensitivity of Psychological Counseling and Guidance students and examine it in terms of various variables, "Intercultural Sensitivity Scale" which was developed by Chen and Starosta (2000) and adapted into Turkish by Bulduk, Tosun, and Ardıç (2011) and consisted of 24 items in 5-point Likert type was utilized as a data collection tool. The original scale was consisted of five dimensions however in this study because of getting unsatisfied fit indices as a result of confirmatory factor analysis conducted; the scale was decided to be used as one-dimensional. Also, in the first adaptation study of the scale, Chen was contacted and his approval was taken for the use of sale as one-dimensional (Üstün, 2011). After checking the normality assumption and when it is met; in order to check the appropriateness of data for factor analysis, Kaiser-Meyer-Olkin and Bartlett's tests were applied. Kaiser-Meyer-Olkin's value was found as .93. This value shows that data are appropriate for factor analysis. As a result of the confirmatory factor analysis conducted, one factor explains $37 \%$ of the variance (eigenvalue $=8.28$ ) and it was found sufficient to use the scale as one-dimensional. Factor load values of the items range from .44 to .73 . Because of having a factor load as .11 , one item (item 19) was excluded from the scale and remaining 23 items consisted the scale. In adaptation study, Cronbach's Alpha internal consistency coefficient was found as .72 but Cronbach's Alpha was found as .91 in this study.

\subsection{Data Analysis}

In order to find out appropriate test statistics for the intercultural sensitivity which is the dependent variable of the study, Kolmogorov-Smirnov and Levene test results were examined. In order to examine whether the intercultural sensitivity perception level of Psychological Counseling and Guidance students significantly differ in terms of "gender", "grade", "change of view on cultural differences arising from their experiences during undergraduate studies" "longest place of settlement", and "being together with other cultures", $t$-test and one-way ANOVA were conducted. The lowest score to be obtained from the scale is 24 points while the highest is 120 points. Arithmetic means were interpreted according to these values. 


\section{Findings and Interpretation}

Descriptive statistics regarding the intercultural sensitivity perception level of Psychological Counseling and Guidance students are presented in Table 3.

Table 3. The perception level of students in terms of grade levels

\begin{tabular}{llllll}
\hline & Grade & $n$ & Item Mean & $\bar{X}$ & $S d$ \\
\cline { 2 - 6 } Intercultural Sensitivity & Freshman & 117 & 3.73 & 85.94 & 13.96 \\
& Sophomore & 143 & 3.90 & 89.86 & 9.93 \\
& Junior & 159 & 3.93 & 90.52 & 9.58 \\
& Senior & 105 & 4.15 & 95.50 & 11.36 \\
& & 524 & 3.92 & 90.31 & 11.54 \\
\hline
\end{tabular}

When Table 3 is examined, it is determined that according to grades, arithmetic mean for PCG freshmen students' perception level of intercultural sensitivity is moderate $(X=85.94)$, while for the sophomore $(X=89.86)$, the junior $(X=90.52)$ and the senior's (95.50) perception levels of intercultural sensitivity are high. This finding shows that the more grade level rises, the more students' perception level of intercultural sensitivity increases, as well. Besides, it was also found that the grand mean of PCG students' intercultural sensitivity was high $(\mathrm{X}=$ 90.31).

Table 4. The results of the analysis based on the intercultural sensitivity scale in terms of gender

\begin{tabular}{cccccccc}
\hline & Gender & $\mathrm{n}$ & & $\mathrm{Sd}$ & $\mathrm{df}$ & $t$ & $p$ \\
\hline \multirow{2}{*}{ Intercultural Sensitivity } & Female & 373 & 86.44 & 10.93 & \multirow{2}{*}{522} & \multirow{2}{*}{.423} & \multirow{2}{*}{.673} \\
& Male & 151 & 86.89 & 10.95 & & & \\
\hline
\end{tabular}

$p>.05$.

When Table 4 is examined, there was no significant difference between students' perception level of intercultural sensitivity in terms of gender $\left(\mathrm{t}_{522}=.423, \mathrm{p}>.05\right)$. It might be concluded that gender is not an effective factor determining PCG students' perception level of intercultural sensitivity.

Table 5. The Mean, standard deviation and one-way ANOVA results of intercultural sensitivity scale points in terms of grade

\begin{tabular}{|c|c|c|c|c|c|c|c|c|}
\hline & Grade & $\mathrm{n}$ & & $S d$ & $d f$ & $F$ & $p$ & Significant difference \\
\hline \multirow{4}{*}{ Intercultural Sensitivity } & 1. Freshman & 117 & 85.94 & 13.96 & \multirow{4}{*}{$3 / 520$} & \multirow{4}{*}{13.701} & \multirow{4}{*}{.000} & \multirow{4}{*}{$3-1,4-1,4-2,4-3$} \\
\hline & 2. Sophomore & 143 & 89.86 & 9.93 & & & & \\
\hline & 3. Junior & 159 & 90.52 & 9.58 & & & & \\
\hline & 4. Senior & 105 & 95.50 & 11.36 & & & & \\
\hline
\end{tabular}

In Table 5, it was found that as a result of the one-way ANOVA conducted in order to find out whether the intercultural sensitivity perception levels of PCG students differ significantly in terms of grade levels, the difference was found significant $\left(\mathrm{F}_{520}=14.061, \mathrm{p}<.05\right)$. In order to find out between which means there is a difference, Dunnett $C$ test which is used when variances are not homogenous (Büyüköztürk, 2010) was applied and it was found that the intercultural sensitivity perception level of senior students significantly differs from freshmen, sophomore and junior students' perception levels. In addition, the intercultural sensitivity perception level of junior students significantly differs from freshmen's perception level. Furthermore, it was found that the intercultural sensitivity perception level of senior students $(X=95.50)$ is higher than freshmen $(X=85.94)$, sophomore $(X=89.86)$ and junior $(X=90.52)$ students' intercultural sensitivity perception levels; and junior students' perception level of intercultural sensitivity was higher than the freshmen's perception level of intercultural sensitivity. In that sense, it might be deduced that the intercultural sensitivity perception level of freshmen students increases in junior and senior grades. 
Table 6. The Mean, standard deviation and one-way ANOVA results of intercultural sensitivity scale points in terms of change of view on cultural differences arising from their experiences during undergraduate studies

\begin{tabular}{ccccccccc}
\hline & Views on Cultural Differences & $n$ & & $S d$ & $d f$ & $F$ & $p$ & Significant difference \\
\hline \multirow{4}{*}{ Intercultural Sensitivity } & Positive & 422 & 91.16 & 11.52 & & & & \\
& Negative & 22 & 86.09 & 9.02 & $2 / 521$ & 6.00 & .003 & Positive-No difference \\
& No difference & 80 & 87.01 & 11.51 & & & & \\
\hline
\end{tabular}

The results of the analysis in Table 6 show that the intercultural sensitivity perception levels of PCG students significantly differ in terms of the change of view on cultural differences arising from their experiences during undergraduate studies $\left(\mathrm{F}_{521}=6.00, \mathrm{p}<.05\right)$. According to Scheffe test results conducted in order to find out between which means there are differences, it was found that the perception level of the ones who stated that the experiences that I had during my undergraduate studies positively changed my view on cultural differences $(\mathrm{X}=91.16, \mathrm{Sd}=11.52)$ was higher than the ones stated no changes occurred $(\mathrm{X}=87.01, \mathrm{Sd}=11.51)$.

Table 7. The Mean, standard deviation and one-way ANOVA results of intercultural sensitivity scale points in terms of students' longest place of settlement

\begin{tabular}{|c|c|c|c|c|c|c|c|c|}
\hline & The longest place of settlement & $n$ & & $S d$ & $d f$ & $F$ & $p$ & Significant difference \\
\hline \multirow{5}{*}{ Intercultural Sensitivity } & Metropolitan & 181 & 91.78 & 11.29 & \multirow{5}{*}{$4 / 519$} & \multirow{5}{*}{4.366} & \multirow{5}{*}{.002} & \multirow{5}{*}{ Metropolitan-County } \\
\hline & Small City & 105 & 91.23 & 9.99 & & & & \\
\hline & County & 161 & 87.97 & 11.30 & & & & \\
\hline & Town & 30 & 86.25 & 9.34 & & & & \\
\hline & Village & 47 & 87.52 & 11.07 & & & & \\
\hline
\end{tabular}

When Table 7 is examined, it was found that as a result of one-way ANOVA which was conducted to find out whether the intercultural sensitivity perception levels of PCG students significantly differ in terms of the longest place of settlement, there is a significant difference $\left(\mathrm{F}_{519}=4.366, \mathrm{p}<.05\right)$. According to the results of Scheffe test which was conducted in order to find out between which means there are differences, it was determined that the perception level of the ones who spent most of their lives in a metropolitan $(X=91.78, \mathrm{Sd}=11.29)$ was higher than the perception level of the ones who spent most of their lives in a county $(X=87.97, \mathrm{Sd}=11.30)$.

Table 8. The t-test results of intercultural sensitivity scale points in terms of students' being together with people from other cultures

\begin{tabular}{cccccccc}
\hline & Being together & $n$ & & $S d$ & $d f$ & $t$ & $p$ \\
\hline \multirow{2}{*}{ Intercultural Sensitivity } & Yes & 428 & 90.84 & 10.80 & \multirow{2}{*}{522} & 4.615 & $.000^{*}$ \\
& No & 96 & 85.18 & 11.09 & & & \\
\hline
\end{tabular}

${ }^{*} \mathrm{p}<.05$.

When Table 8 is examined, the intercultural sensitivity perception levels of students significantly differ according to the variable of being together with people from other cultures $\left(t_{522}=4.615, p<.05\right)$. It is determined that the perception levels of students who stated that they are together with people from other cultures $(X=90.84)$ are higher than the perception levels of students who stated that they are not $(X=85.18)$.

\section{Conclusion, Discussion and Suggestions}

The purpose of this study is to examine Psychological Counseling and Guidance students' perception level of intercultural sensitivity in terms of various variables. It was found that there is no significant difference in psychological counseling candidates' perception level of intercultural sensitivity in terms of gender. This finding is in line with the findings of the studies which examined the effect of gender on intercultural sensitivity (Chen \& Starosta, 2000; Rengi \& Polat, 2014; Spinthourakis, Karatzia-Stavlioti \& Roussakis, 2009; Üstün, 2011; Y1lmaz \& Göçen, 2013). Besides, it has also emerged that there are research studies which claim that the mean of the total score which female students got from the scale significantly differs from the mean of the total score which male students got from the scale (Banos, 2006; Holm, Nokelainen \& Tirri, 2009; Banos, 2006). In literature, it is possible to find contradictory study results which examined the effect of gender on intercultural sensitivity 
perception. As a consequence, it might be concluded that gender is not an effective variable that determines the level of intercultural sensitivity.

Another finding of the study is that the intercultural sensitivity perception level of senior students significantly differs from the freshman, sophomore and junior students' perception level. The difference in perception levels of PCG students in terms of grade might be explained by that some courses offered in the PCG department might support the development of intercultural sensitivity. Thus, when PCG undergraduate program is examined, it was seen that "Communication in Family" and "Life Periods and Adaptation Problems" courses offered in 3 rd grade and "Cultural and Social Change" and "Individual Counseling Practices" and "Family Guidance in Special Education" courses offered in $4^{\text {th }}$ grade have attainments that aiming to develop intercultural sensitivity. In addition, another finding of the study showed that the perception levels of the ones who stated that the experiences that I had during my undergraduate studies positively changed my view on cultural differences were higher than the ones stated no changes occurred. This finding is congruent with the finding of having a difference in perception levels in terms of grade levels. Erdur-Baker (2007) also asserts that there is a need to train PCG students by making them being aware of their counselees' cultural differences. In the study conducted with students of Primary Education department by Yllmaz and Göçen (2013), it was found that the intercultural sensitivity perception level doesn't differ in terms of grade level. In that sense, it might be interpreted that PCG undergraduate program might have a contribution to the increase in PCG students' perception level of intercultural sensitivity in terms of grade levels.

According to another finding of this research, the intercultural sensitivity perception level of PCG students significantly differs in terms of their longest place of settlement. It was determined that the perception level of the ones who spent most of their lives in a metropolitan was higher than the perception level of the ones who spent most of their lives in a county. In the study conducted with teacher candidates by Üstün (2011), it was found that the intercultural sensitivity perception level of the ones who live in a city is higher than the perception level of the ones who live in other places rather than a city. It might be said that when the size of the place of settlement gets bigger, due to getting various sub-cultures together and the necessity of living together, intercultural sensitivity perception levels may improve.

In this study, it is determined that the intercultural sensitivity perception level of students who stated that they are together with people from other cultures is higher than intercultural sensitivity perception level of students who stated that they are not. It might be concluded that when individuals know various different cultural contexts apart from their own culture, their respect and tolerance for differences may develop. Üstün (2011) also supports such findings in the study conducted with teacher candidates. Also, in a quantitative study conducted by A. Demir and S. Demir (2009), it was claimed that teacher candidates who go abroad with Erasmus program stated that such an experience helps them to get more tolerance for others and help them to put their prejudices away. This finding is also consistent with the relevant literature.

Based on the research findings, in brief, it is found that when grade level rises, the intercultural sensitivity perception level of students also increases and students' positive experiences in their undergraduate studies are effective in this perception increase. In addition, it is also determined that in terms of the longest place of settlement; the ones who live in a metropolitan rather than a county and also the ones who are together with people from other cultures than the ones who are not together with people from other cultures have higher perception level of intercultural sensitivity. In a nutshell, it is found that the factors which affect intercultural sensitivity perception level of students who study in Psychological counseling and guidance undergraduate program are such; grade level, the experience in the undergraduate program, the longest place of settlement, and being together with other cultures.

The following implications are presented based on the study results.

1) It has emerged that the experience gained during PCG undergraduate study is positively affecting students' intercultural sensitivity perception level. In that reason, more culturally sensitive psychological counseling studies might be included in PGC curriculum.

2) When students who are with different cultures are thought to have a higher level of perceived intercultural sensitivity, thus, making widespread of international and national student exchange programs such as ERASMUS and FARABI and arranging educational settings by giving place for interaction with various cultures might be suggested.

3) The results of this study are limited to the assessment tool which was based on self-report. For that reason, the study results should be supported by studies conducted with techniques such as observation, interview and etc. 
4) This study was conducted with the students of Psychological Counseling and Guidance program of Faculty of Education at Pamukkale University. Similar studies might be conducted with PCG students from different universities and further research studies which aim to compare results of such studies might also be conducted.

5) In-depth research studies might be conducted in order to determine the effect of PCG undergraduate programs which is one of the factors that affect PCG students' perception level of intercultural sensitivity.

\section{References}

Auernheimer, G. (2010). Interkulturelle kommunikation, mehrdimensional betrachtet, mit konsequenzen für das verständnis interkultureller kompetenz. In G. Auernheimer (Hg.), Interkulturelle kompetenz und pädagogische professionalität (pp. 35-65). Wiesbaden: VS Verlag für Sozialwissenschaften. https://doi.org/10.1007/978-3-531-92312-3_3

Aydın, B. (2014). Kültüre duyarlı psikolojik danışma eğitiminin psikolojik danışman adaylarının kültürel duyarlılık düzeyleri üzerindeki etkisi [The effect of culturally sensitive counseling training program on cultural sensitivity levels of counselor candidates] (Yayınlanmamaış doktora tezi) [Unpublished doctoral dissertation]. Karadeniz Teknik Üniversitesi Eğitim Bilimleri Enstitüsü, Trabzon.

Banos, R. V. (2006). Intercultural sensitivity of teenagers: a study of educational necessities in Catalonia. Intercultural Communication Studies, 15(2), 16-22

Baykara B. (2010). Yabancı dil eğitiminde kültürlerarasılık [Interculturalism in foreign language education] (Yayımlanmamış yüksek lisans tezi) [Unpublished master's thesis] Frrat Üniversitesi Sosyal Bilimler Enstitüsü, Elazı̆̆g.

Bekiroğlu, O., \& Balcı, Ş. (2014). Kültürlerarası iletişim duyarlılığının izlerini aramak: iletişim fakültesi öğrencileri örneğinde bir araştırma. Selçuk Üniversitesi Türkiyat Araştırmaları Dergisi, 35, 429-459. https://doi.org/10.21563/sutad.187110

Bektaş, Y. (2006). Kültüre duyarlı psikolojik danışma yeterlikleri ve psikolojik danışman eğitimindeki yeri [Multicultural Counseling Competences and The Place of Multicultural Competences in Counseling Education]. Ege Ĕ̈itim Dergisi, 7(1), 43-59

Bennett, J. M. (1993). Toward ethnorelativism: A developmental model of intercultural sensitivity. In R. M. Paige (Ed.), Education for the intercultural experience (pp. 21-71), Yarmouth, ME: Intercultural Press.

Bolten, J. (2007). Interkulturelle kompetenz. Erfurt: Druckerei Sömmerda GmbH.

Bulduk, S., Tosun, H. \& Ardıç, E. (2011). Türkçe kültürler arası duyarlılık ölçeğinin hemşirelik öğrencilerinde ölçümsel özellikleri [Measurement properties of Turkish intercultural sensitivity scale among nursing students]. Turkiye Klinikleri J Med Ethics, 19(1), 25-31.

Büyüköztürk, Ş. (2010). Sosyal bilimler için veri analizi el kitabı: Istatistik araştırma deseni, SPSS uygulamları ve yorum. Ankara: Pegem Yayınları

Byram, M. (1997). Teaching and assessing intercultural communication competence. New York: Multilingual Matters. Retrieved from https://books.google.com.tr/books?id=0vfq8JJWhTsC\&printsec=frontcover\&hl=tr \&source $=\mathrm{gbs}$

Byram, M., Gribkova, B., \& Starkey, H. (2002). Developing the intercultural dimension in language teaching: A practical introduction for teachers. The Council of Europe. Retrieved from http://lrc.cornell.edu/director/intercultural.pdf

Chen, G. M., \& Starosta, W. J. (1996). Intercultural communication competence: A synthesis. Communication Yearbook, 19, 353-384. https://doi.org/10.1080/23808985.1996.11678935

Chen, G. M. (1997, January). A Review of the concept of intercultural sensitivity. Paper presented at the biennial convention of Pacific and Asian Communication Association, Honolulu, Hawaii.

Chen, G. M., \& Starosta, W. J. (2000, November). The development and validation of the intercultural sensitivity scale. Paper presented at the Annual Meeting of the National Communication Association, Seattle, WA.

Deardorff, D. K. (2006). Identification and assessment of intercultural competence as a student outcome of internationalization. Journal of Studies in Intercultural Education, 10(3), 241-266. https://doi.org/10.1177/1028315306287002

Demir, A. \& Demir, S. (2009) Erasmus programının kültürlerarası diyalog ve etkileşim açısından 
değerlendirilmesi: öğretmen adaylarıyla nitel bir çalışma. (The assesment of erasmus program in terms of intercultural dialogue and interaction. a qualitative study with candidate teachers). Uluslararast Sosyal Araştırmalar Dergisi (The Journal of International Social Research), 2(9), 95-105.

Erdur-Baker, Ö. (2007). Psikolojik danışma ve kültürel faktörler. Türk Psikolojik Danışma ve Rehberlik Dergisi. 3(27), 109-122

Güvenç, B. (1997). Kültürün abc’si. İstanbul: Yapı Kredi Yayınları.

Harmandaoğlu, E. (2013). Promottng intercultural competence of teacher trainees in english language departments vla web 2.0 tools: A case study (Unpublished master's thesis). Gazı University The Institute of Educatıonal Sciences, Ankara.

Hesse, H. -G. \& Göbel, K. (2007). Interkulturelle kompetenz. In B. Beck, \& E. Klieme (Eds.), Sprachliche kompotenzen konzepte und messung (pp. 256-272). Weinheim und Basel: Beltz Verlag.

Holm, K., Nokelainen, P., \& Tirri, K. (2009). Relationship of gender and academic achievement to Finnish students' intercultural sensitivity. High Ability Studies, 20(2), 187-200. https://doi.org/10.1080/13598130903358543

Howard-Hamilton, M. F., Richardson, B. J., \& Shuford, B. (1998). Promoting multicultural education: A holistic approach. College Student Affairs Journal, 18, 5-17.

Imahori, T. T., \& Lanigan, M. L. (1989). Relational model of intercultural communication competence. Intercultural Communication Competence, 13, 269-286. https://doi.org/10.1016/0147-1767(89)90013-8

Kagnici, D. Y. (2014). Reflections of a Multicultural Counseling Course: A Qualitative Study with Counseling Students and Counselors. Educational Sciences: Theory and Practice, 14(1), 53-62. https://doi.org/10.12738/estp.2014.1.1965

Karaırmak, Ö. (2008). Çok kültürlülük, kültürel duyarlılık ve psikolojik danışma. Türk Psikolojik Danısma ve Rehberlik Dergisi, 3(29), 115-129.

Leclerqc, J.-M. (2003). Facets of interculturality in education. Responses to violence in everyday life in a democratic society. Strasbourg: Council of Europe Publishing. Retrieved from http://www.peacepalacelibrary.nl/ebooks/files/Coe18.pdf

Rengi, Ö., \& Polat, S. (2014). Sınıf öğretmenlerinin kültürel farklılık algıları ve kültürlerarası duyarlılıkları [Primary teachers' perception of cultural diversity and intercultural sensitivity]. Zeitschrift für die Welt der Türken, 6(3), 135-156.

Spinthourakis, J. A., Karatzia-Stavlioti, E., \& Roussakis, Y. (2009). Pre-service teacher intercultural sensitivity assessment as a basis for addressing multiculturalism. Intercultural Education, 20(3), 267-276. https://doi.org/10.1080/14675980903138624

Spitzberg, B. H., \& Changnon, G. (2009). Conceptualizing intercultural competence. In D. K. Deardorf (Ed.), The SAGE handbook of intercultural competence (pp. 1-52). California: Sage

Tertemiz, N., \& Aslantaş, S. (2016). Çokkültürlü eğitime dayalı proje çalışmasının sınıf öğretmeni adaylarının kültürlerarası duyarlılık düzeylerine etkisi. Ufuk Üniversitesi Sosyal Bilimler Enstitüsü Dergisi, 5(9), 7-22

Üstün, E. (2011) Öğretmen adaylarının kültürlererası duyarlllı ve etnikmerkezcilik düzeylerini etkileyen etmenler [Factors affecting teacher candidates' intercultural sensitivity and ethnocentrism levels] (Yayımlanmamış yüksek lisans tezi) (Unpublished master's thesis), Yıldız Teknik Üniversitesi Sosyal Bilimler Enstitüsü, İstanbul.

Yılmaz, F., \& Göçen, S. (2013). Sınıf öğretmeni adaylarının kültürlerarası duyarlılık hakkındaki görüşlerinin farklı değişkenlere göre incelenmesi. Adlyaman Üniversitesi Sosyal Bilimler Enstitüsü Dergisi, 6(15), 373-392. https://doi.org/10.14520/adyusbd.649

\section{Copyrights}

Copyright for this article is retained by the author(s), with first publication rights granted to the journal.

This is an open-access article distributed under the terms and conditions of the Creative Commons Attribution license (http://creativecommons.org/licenses/by/4.0/). 